\title{
KOMUNIKASI MATEMATIS DAN DISPOSISI BERPIKIR KRITIS MAHASISWA PENDIDIKAN MATEMATIKA PADA MATA KULIAH MATEMATIKA DISKRIT
}

\author{
Tri Nopriana ${ }^{1}$, Muchamad Subali Noto ${ }^{2}$ \\ ${ }^{1,2}$ Prodi Pendidikan Matematika, FKIP, Universitas Swadaya Gunung Jati \\ Email: riatrinopriana@gmail.com
}

\begin{abstract}
ABSTRAK
Tujuan dari penelitian ini adalah untuk mengembangkan kemampuan komunikasi matematis dan mengukur disposisi berpikir kritis mahasiswa pendidikan matematika melalui pendekatan pembelajaran Student Centered pada mata kuliah Matematika Diskrit. Penelitian ini merupakan penelitian deskriptif kualitatif. Subjek penelitian adalah mahasiswa Unswagati tingkat 2 sebanyak 2 kelas yang terdiri dari 40 mahasiswa. Metode pengumpulan data yang digunakan meliputi: (1) tes komunikasi matematis pada pokok bahasan Graf dan Pohon, serta (2) Skala Disposisi Berpikir Kritis dengan 5 kategori skal model Likert. Data dianalisis secara deskriptif. Hasil penelitian didapatkan: (1) Peningkatan kemampuan komunikasi matematis mahasiswa secara keseluruhan cukup signifikan dengan kategori ngain sedang. Selain itu, peningkatan kemampuan komunikasi matematis mahasiswa berdasarkan Kemampuan Awal Matematis (KAM) tinggi dan sedang cukup signifikan dengan kategori n-gain sedang, sedangkan untuk kelompok mahasiswa dengan KAM rendah, peningkatan kemamuan komunikasi matematis masih tergolong rendah. (2) Secara keseluruhan disposisi berpikir kritis mahasiswa setelah mendapat pembelajaran dengan pendekatan Student Centered, tergolong baik, dengan rata-rata pencapaian skala disposisi berpikir kritis sebesar $76 \%$. Sejalan dengan itu, pada masing-masing kelompok KAM, pencapaian skala disposisi berpikir kritis mahasiswa masih tergolong baik. Mahasiswa pada kategori KAM tinggi memperoleh pencapaian skala disposisi berpikir kritis sebesar 77\%, 76 $\%$ pada mahasiswa dengan kategori KAM sedang dan $72 \%$ pada mahasiswa dengan kategori KAM rendah.
\end{abstract}

Kata kunci: Komunikasi Matematis, Disposisi Berpikir Kritis dan Pembelajaran Student Centered. 


\section{PENDAHULUAN}

Pembelajaran di kelas pada dasarnya merupakan proses komunikasi, antara guru dan siswa dalam penyampaian materi, penggunaan media dan penerimaan materi. Pada pembelajaran matematika, materi yang disampaikan oleh pengajar disampaikan dalam bentuk verbal maupun non verbal. Menurut (NCTM, 2000) seorang calon guru matematika harus memiliki kemampuan mengkomunikasikan pikiran matematisnya dengan indicator (1) mengkomunikasikan pikiran matematisnya secara koheren dan jelas kepada teman-temannya, para dosen dan kepada lainnya; (2) menggunakan bahasa matematika untuk mengekspresikan ide/gagasan secara tepat; (3) mengelola pemikiran matematisnya melalui komunikasi, dan (4) menganalisis dan mengevaluasi pikiran matematis dan strategi-strategi orang lain.

Kemampuan-kemampuan matematis yang harus dimiliki oleh siswa pada jenjang pendidikan dasar dan menengah juga harus dimiliki oleh mahasiswa calon guru yang akan mengajarkan matematika. Committee on the Undergraduate Program in Mathematics (CUPM) (Karmilah, 2010) memberikan enam rekomendasi dasar untuk jurusan, program, dan mata kuliah dalam matematika. Salah satu rekomendasinya menerangkan bahwa setiap mata kuliah dalam matematika hendaknya merupakan aktivitas yang akan membantu mahasiswa dalam pengembangan analitis, penalaran kritis, pemecahan masalah, dan keterampilan komunikasi. Rekomendasi CUPM di atas menerangkan, tugas lembaga pendidikan yang bertugas mendidik calon guru yang akan mengajarkan matematika, diantaranya adalah mempersiapkan mahasiswa-mahasiswinya untuk memiliki kemampuan komunikasi dan berpikir kritis matematis.

Hasil pengamatan yang dilakukan Supriadi (2010) tahun 2005 selama beberapa semester terhadap mahasiswa calon guru matematik yang berasal dari SMA, SMK, MA dan SPG ternyata kurang memuaskan dengan diperolehnya rerata kurang dari 50\% dari skor maksimal untuk kelompok tersebut. Mahasiswa masih kesulitan memahami matematika yang dipandangnya sebagai mata kuliah yang paling sulit dan tidak menyenangkan. Ekspresi, komunikasi, dan kemampuan berpikir matematika diantara mahasiswa masih kurang. Selain itu, (Angraini, 2013) dalam penelitiannya masih menemukan kesalahan-kesalahan yang dilakukan oleh mahasiswa dalam menyelesaikan soal kemampuan matematis. Rata-rata nilai kemampuan komunikasi matematis mahasiswa secara keseluruhan hanya 6,9. Berdasarkan uraian di atas, peneliti merasa perlu untuk mengembangkan kemampuan komunikasi matematis mahasiswa prodi pendidikan matematika FKIP Unswagati sebagai salah satu lembaga pendidikan pencetak calon guru matematika pada tingkat menengah sejak dini.

Selain kemampuan komunikasi matematis, mahasiswa pendidikan matematika perlu mengembangkan aspek afektif mereka. Pemikiran seseorang, sulit akurat apabila kondisi afektifnya kurang baik. Sikap atau disposisi yang kurang baik akan mempengaruhi kemampuan-kemampuan untuk mengamati dan menganalisis dengan cermat sehingga akan mempengaruhi kualitas keputusan yang diambil (Cottrell, 2005). Disposisi adalah kecendrungan atau kebiasaan untuk berpikir dalam cara dan kondisi tertentu.

Berpikir yang akan dibahas pada penelitian ini merupakan kecenderungan berpikir kritis. Sesuai dengan tujuan pembelajaran tingkat tinggi, yaitu mengembangkan kemampuan berpikir kritis mahasiswa. Berpikir kritis merupakan suatu proses berujung pada pembuatan kesimpulan atau keputusan yang logis tentang apa yang harus diyakini dan tindakan apa yang harus dilakukan.

Mahasiswa yang memiliki disposisi berpikir kritis akan cenderung berpikir kritis ketika ada situasi atau kondisi yang menghadirkan stimulus untuk berpikir kritis. 
Disposisi berpikir kritis merupakan sifat yang melekat pada diri seseorang yang berpikir kritis. Contoh: menunjukkan sikap positif jika diperhadapkan dengan persoalan yang berhubungan dengan matematika. Penelitian yang dilakukan oleh (Rosita \& Nopriana, 2016) menyimpulkan bahwa kemampuan disposisi berpikir kritis mahasiswa pendidikan matematika tergolong baik, namun untuk lebih menganalisis lebih rinci kemampuan disposisi berpikir kritis mahasiswa, penulis merasa perlu untuk melakukan penelitian lebih lanjut mengenai kemampuan tersebut.

Pendekatan pembelajaran yang dapat mengembangkan kedua kemampuan di atas, diantaranya adalah pendekatan pembelajaran Student Centered, pembelajaran ini menempatkan mahasiswa sebagai peserta didik yang aktiv dan mandiri dan bertanggung jawab sepenuhnya selama pembelajaran. Model kooperatif merupakan salah satu model pembelajaran yang sesuai dengan karakteristik pendekatan Student Centered. Belajar secara berkelompok memungkinkan mahasiswa untuk mengembangkan kemampuan komunikasi matematis dan disposisi berpikir kritis mereka secara aktiv dan mandiri.

Salah satu mata kuliah wajib yang harus diambil oleh mahasiswa pendidikan matematika FKIP Unswagatai adalah mata kuliah Matematika Diskrit. Mata kuliah ini menyajikan beberapa pokok bahasan yang menuntut siswa untuk memiliki kemampuan komunikasi matematis dan disposisi berpikir kritis, diantaranya pokok bahasan Graf dan Pohon. Pada pokok bahasan tersebut, mahasiswa dituntut untuk dapat menyatakan peristiwa sehari-hari dalam symbol matematis, membaca gambar dan symbol matematis dengan pemahaman matematis tertulis dan menjelaskan ide, situasi, dan relasi matematis dengan gambar. Selain itu, pembelajaran menggunakaan pendekatan Student Centered melalui model pembelajaran kooperatif memungkinkan mahasiswa untuk memiliki kecenderungan untuk: (1) Bertanya secara jelas dan beralasan; (2) Berusaha memahami dengan baik; (3) Menggunakan sumber yang terpercaya; (4) Mencari berbagai alternatif; (5) Tetap mengacu/ relevan ke masalah pokok; (6) Bersikap terbuka, berani mengambil posisi; (7) Bertindak cepat; (8) Memandang sesuatu secara menyeluruh; (9) Memanfaatkan cara berpikir orang yang kritis; (10) Bersikap sensitif terhadap perasaan orang lain

Berdasarkan paparan di atas, peneliti menilai perlu untuk melakukan penelitian terkait upaya mengembang kemampuan komunikasi matematis dan disposisi berpikir kritis mahasiswa melalui pendekatan pembelajaran Student Centered khususnya pada mata kuliah Matematika Diskrit.

Berdasarkan masalah penelitian yang telah dirumuskan di atas, maka penelitian ini secara khusus bertujuan untuk: 1) meningkatkan kemampuan komunikasi matematis pada mata kuliah matematika diskrit melalui model pembelajaran student centered; 2) mengukur disposisi berpikir kritis mahasiswa pada mata kuliah matematika diskrit melalui model pembelajaran student centered.

Hasil penelitian ini terutama diharapkan bermanfaat bagi staf dosen dan pengelola Program Studi Pendidikan Matematika FKIP Unswagati sebagai bahan pertimbangan dalam melakukan upaya-upaya peningkatan kualitas mahasiswa pendidikan matematika, khususnya dalam mengembangkan strategi perkuliahan untuk meningkatkan kemampuan komunikasi dan disposisi berpikir kritis mahasiswa.

Target luaran yang diharapkan tercapai setelah penelitian ini dilaksanakan adalah mempublikasikan hasil penelitian melalui publikasi ilmiah, prosiding, dan pengayaan bahan ajar matematika diskrit. Dengan demikian diharapkan hasil penelitian dapat bermanfaat secara luas, tidak hanya di lingkungan Unswagati tapi juga perguruan tinggi lainnya. 


\section{MOTODE PENELITIAN}

Penelitian ini menggunakan metode penelitian quasi eksperimen dengan menggunakan desain One-Group PretestPostest. Populasi dalam penelitian ini adalah seluruh mahasiswa tingkat II Prodi Pendidikan Matematika Tahun Akademik 2015/2016. Berdasarkan populasi tersebut dipilih 40 mahasisswa sebagai sampel secara acak dari 4 kelas yang diampu oleh peneliti pada mata kuliah Matematika Diskrit.

Kemampuan awal matematis (KAM) mahasiswa diperoleh dari nilai tes mata kuliah Matematika Diskrit pada pokok bahasan kombinatorik. Nilai UTS mahasiswa dikelompokan berdasarkan kategori kemampuan awal tinggi, sedang dan rendah. Kriteria pengelompokan KAM berdasarkan kepada rata-rata $(\bar{X})$ dan simpangan baku $(s)$, kriteria yang digunakan adalah:

Tabel 1

Kriteria Pengelompokan KAM

\begin{tabular}{lc}
\hline $\mathrm{KAM} \geq \bar{X}+s$ & $\begin{array}{c}\text { Mahasiswa } \\
\text { kelompok tinggi }\end{array}$ \\
\hline $\bar{X}-s \leq \mathrm{KAM}<\bar{X}+s$ & $\begin{array}{c}\text { Mahasiswa } \\
\text { kelompok } \\
\text { sedang }\end{array}$ \\
\hline $\mathrm{KAM}<\bar{X}-s$ & $\begin{array}{c}\text { Mahasiswa } \\
\text { kelompok tinggi }\end{array}$ \\
\hline
\end{tabular}

INSTRUMEN PENELITIAN

Tes kemampuan komunikasi

matematis yang digunakan dalam penelitian ini memuat pokok bahasan Graf dan Pohon. Tes terdiri dari 4 buah pertanyaan dalam bentuk essay dengan skor maksimal 70 . Tes disusun berdasarkan 3 buah indikator kemampuan komunikasi matematis diantaranya (1) Menyatakan peristiwa seharihari dalam symbol matematis; (2) Membaca gambar dan symbol matematis dengan pemahaman matematis tertulis; Menjelaskan ide, situasi, dan relasi matematis dengan gambar.

Skala disposisi berpikir kritis dalam penelitian ini digunakan untuk mengetahui disposisi mahasiswa dalam berpikir kritis khususnya pada pokok bahasan Graf dan
Pohon. Skala disposisi berpikir kritis diberikan kepada mahasiswa setelah melakukan pembelajaran dengan pendekatan Student Centered. Aspek yang diukur pada skala ini adalah (1) Bertanya secara jelas dan beralasan; (2) Berusaha memahami dengan baik; (3) Menggunakan sumber yang terpercaya; (4) Mencari berbagai alternatif;

Skala disposisi matematis yang digunakan pada penelitian ini, merupakan skala disposisi berpikir kritis yang telah disusun oleh (Angraini, 2013), skala disposisi tersebut terdiri atas 30 pernyataan dengan 5 kategori skala model Likert, yaitu Sangat Sering (SS), Sering (S), Jarang (J), Tidak Sering (TS) dan Sangat Tidak Sering (STS). Skala disposisi disusun atas dua tipe pernyataan, yaitu pernyataan positif dan pernyataan negatif.

\section{TEKNIK PENGOLAHAN DATA}

Setelah data terkumpul, analisis yang digunakan adalah analisis deskriptif kualitatif kuantitatif, dalam suharsimi arikunto djelaskan bahwa: Analisis deskriptif kuantitatif adalah adalah teknik yang digunakan untuk menganalisis data dengan cara mencari jumlah frekuensi dan mencari jumlah presentasinya.

\section{TES KEMPUAN KOMUNIKASI}

Setelah diperoleh skor pretes dan postes, untuk mengetahui peningkatan kemampuan komunikasi matematis mahasiswa melalui pembelajaran dengan pendekatan Student Centered dihitung dengan menggunakan rumus gain ternormalisasi yang dikemukakan oleh Meltzer (2002: 3), sebagai berikut:

$$
g=\frac{\text { skor postes }- \text { skor pretes }}{\text { skor maksimal ideal - skor pretes }}
$$

Kriteria interpretasi menurut Hake (1999:1) adalah:

Tabel 2 Interpretasi Gain Ternormalisasi

\begin{tabular}{cc}
\hline Nilai $\mathbf{g}$ & Klasifikasi \\
\hline$g>0,7$ & Tinggi \\
\hline $0,3<g \leq 0,7$ & Sedang \\
\hline$g \leq 0,3$ & Rendah \\
\hline
\end{tabular}


DISPOSISI BERPIKIR KRITIS

Data yang diperoleh dari skala disposisi berpikir kritis kemudian dianalisis dengan menggunakan rumus berikut:
Persentase Diposisi Berpikir Kritis = $\frac{\text { Srata-rata skor disposisi berpikir kritis }}{\sum \text { skor maksimum }} \times 100 \%$ (Jihad dan Haris, 2010: 125)

\section{Tabel 3}

Tolak Ukur Menentukan Kualitas Rata-rata Disposisi Berpikir Kritis Mahasiswa

\begin{tabular}{ccc}
\hline No. & Interval Nilai & Kriteria \\
\hline 1 & $90<$ presentase disposisi $\leq 100$ & sangat baik \\
\hline 2 & $70<$ presentase disposisi $\leq 89$ & Baik \\
\hline 3 & $50<$ presentase disposisi $\leq 69$ & Cukup \\
\hline 4 & $30<$ presentase disposisi $\leq 49$ & Kurang \\
\hline 5 & $10<$ presentase disposisi $\leq 29$ & Sangat kurang \\
\hline
\end{tabular}

Sumber: Jihad dan Haris (2010: 131)

\section{HASIL PENELITIAN DAN PEMBAHASAN}

Kemampuan awal matematis (KAM) mahasiswa yang dijadikan sampel pada penelitian ini dapat dilihat dari perolehan nilai Ujian Tengah Semester (UTS) mahasiswa pada mata kuliah matematika diskrit. KAM terdiri dari tiga kategori yaitu: kategori tinggi, kategori sedang dan kategori rendah. Untuk menentukan batas kategori tersebut, dibutuhkan beberapa data hasil nilai UTS dari mahasiswa yang seperti yang dapat terlihat pada Tabel 4 di bawah ini

Tabel 4

Analisis Nilai Kemampuan Awal Matematis

\begin{tabular}{cccclc}
$\begin{array}{c}\text { Jumlah } \\
\begin{array}{c}\text { Mahasiswa } \\
(\mathbf{N})\end{array}\end{array}$ & $\begin{array}{c}\text { Rerata } \\
(\overline{\boldsymbol{X}})\end{array}$ & $\begin{array}{c}\text { Simpangan } \\
\text { Baku }(\boldsymbol{s})\end{array}$ & $\begin{array}{c}\text { KAM Tinggi } \\
(\mathrm{KAM} \geq \overline{\boldsymbol{X}}+\boldsymbol{s})\end{array}$ & $\begin{array}{c}\frac{\text { KAM Sedang }}{(\boldsymbol{X}-\boldsymbol{s} \leq \mathrm{KAM}} \\
<\overline{\boldsymbol{X}}+\boldsymbol{s})\end{array}$ & $\begin{array}{c}\text { KAM Rendah } \\
(\text { KAM } \\
<\overline{\boldsymbol{X}}-\boldsymbol{s})\end{array}$ \\
\hline 40 & 61,53 & 17,14 & KAM $\geq 79)$ & $\begin{array}{l}44 \leq \mathrm{KAM} \\
<79)\end{array}$ & KAM $<44$ \\
\hline
\end{tabular}

Setelah dilakukan perhitungan mengenai pengelompokan kemampuan awal matematis mahasiswa, dari keseluruhan 40 mahasiswa, terdapat 9 mahasiswa yang memiliki kemampuan awal matematis tinggi, 23 mahasiswa pada kelompok kemampuan awal sedang dan 8 mahasiswa yang memiliki kemampuan awal rendah.

\section{KEMAMPUAN KOMUNIKASI MATEMATIS}

Berikut ini akan diberikan deskripsi kemampuan komunikasi matematis mahasiswa sebelum dan setelah mendapat pembelejaran dengan pendekatan Student Centered. Deskripsi statistik kemampuan komunikasi matematis yang dimaksud meliputi jumlah mahasiswa, nilai minimum, maksimal, rerata, rerata gain ternormalisiasi dan kategori gain. Hasil perhitungan tersebut disajikan pada Tabel 5 dibawah ini: 
Tabel 5

Deskripsi Statistik Data Pretes Kemampuan Berpikir Geometri Kedua Kelompok Model Pembelajaran

\begin{tabular}{ccccccc}
\hline Hasil & $\begin{array}{c}\text { Junmlah } \\
\text { Mahasiswa (N) }\end{array}$ & $\boldsymbol{x}_{\text {min }}$ & $\boldsymbol{x}_{\text {maks }}$ & $\overline{\boldsymbol{x}}$ & $\overline{\boldsymbol{x}}$ n-gain & Kategori \\
\cline { 1 - 5 } Pretes & 40 & 5 & 37 & 25,93 & 0.40 & Sedang \\
\hline Postes & 40 & 11 & 86 & 54,25 & & \\
\hline
\end{tabular}

Keterangan: Skor Ideal Tes Kemampuan Komunikasi Matematis 100

Berdasarkan tabel di atas, dapat terlihat bahwa terdapat peningkatan skor minimum dan maksimal mahasiswa setelah mendapat pembelajaran dengan pendekatan student centered, hal ini juga terlihat pada rerata postes yang lebih tinggi daripada rerata pretes. Secara keseluruhan peninggkatan kemampuan komunikasi matematis mahasiswa dapat terlihat pada nilai n-gain yang masuk dalam kategori sedang. Maka dapat disimpulkan terdapat peninggakatan yang cukup signifikan pada kemampuan komunikasi matematis mahasiswa dengan adanya pembelajaran menggunakan pendekatan Student Centered.

Selanjutnya peningkatan kemampuan komunikasi matematis mahasiswa berdasarkan kategori kemampuan awal matematis mahasiswa, dapat dilihat pada tabel 6 berikut:

Tabel 6

Deskripsi Komunikasi Matematis Mahasiswa Berdasarkan Kategori Kemampuan Awal Matematis (KAM)

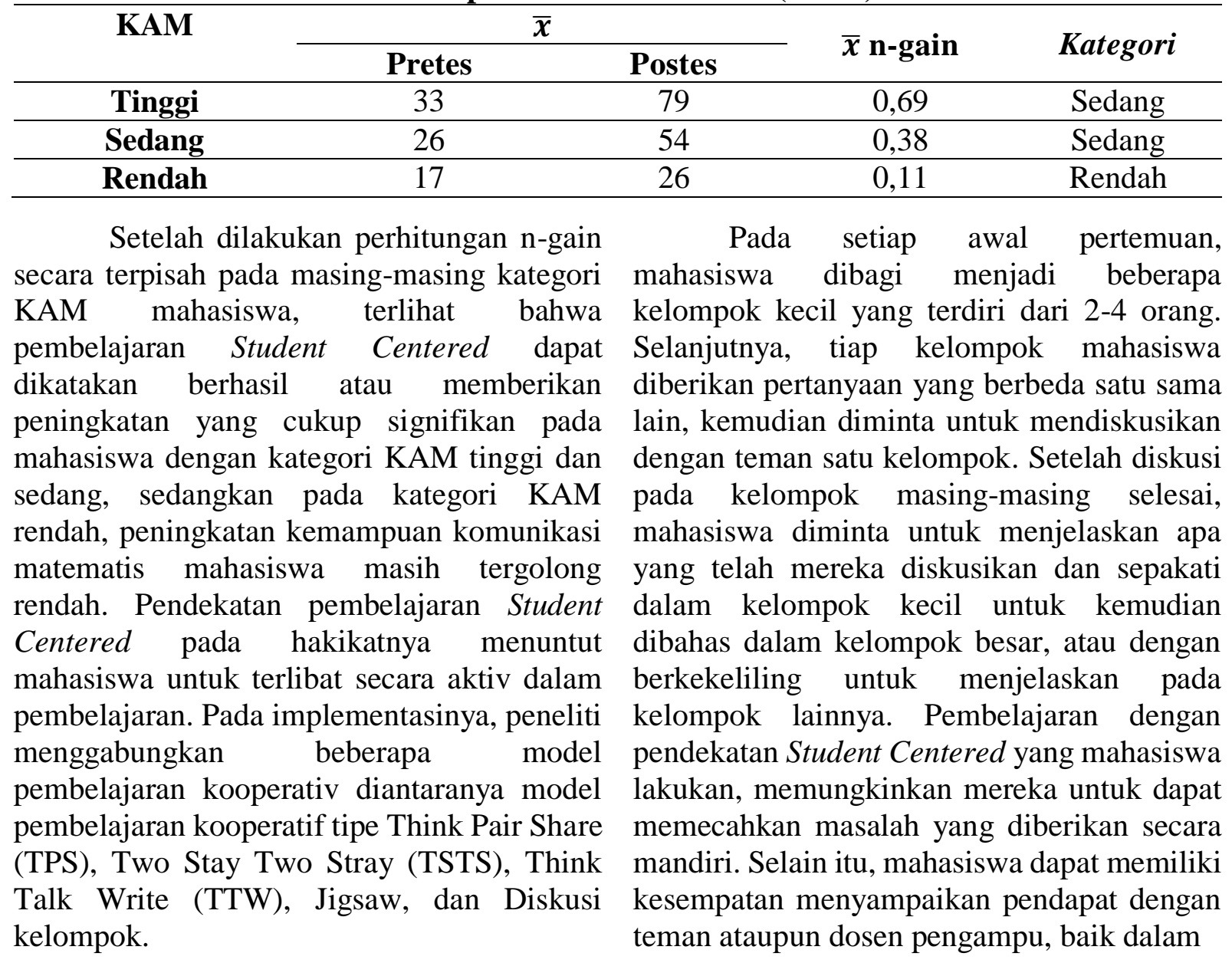


bentuk pertanyaan maupun pada saat menjelaskan materi tertentu. Selain itu, permasalahan-permasalahan yang diberikan kepada mahasiswa merupakan permasalahan sehari-hari yang perlu diselesaikan dengan konsep Graf dan Pohon. Dengan kata lain, dalam menyelesaikan masalah yang diberikan, mahasiswa dituntut untuk dapat mengubah permasalahan yang diberikan dalam bentuk atau symbol matematika yang berkaitan dengan konsep Graf dan Pohon.

Namun pada implementasinya, masih terdapat mahasiswa yang belum secara maksimal melakukan pembelajaran dengan pendekatan student centered, yaitu mahasiswa pada kategori KAM rendah. Mahasiswa pada kategori KAM rendah cenderung mengandalkan teman sekelompoknya untuk menjelaskan atau menyampaikan materi pada kelompok lain, hal ini berakibat pada peningkatan kemampuan komunikasi matematis yang tergolong rendah atau tidak signifikan pada kelompok mahasiswa dengan KAM rendah.

Pembahasan sebelumnya menjelaskan bahwa pembelajaran Student Centered terbukti secara teori dan uji n-gain dapat meningkatkan kemampuan komunikasi matematis mahasiswa secara keseluruhan, maupun secara khusus pada kelompok KAM tinggi dan sedang. Hasil penelitian ini sejalan dengan beberapa penelitian sebelumnya yang dilakukan oleh (Ningsih, 2014) yang menyimpulkan bahwa model pembelajaran Think-Talk-Write (TTW) pada pembelajaran teori bilangan dapat meningkatkan kemampuan komunikasi mahasiswa sehingga mahasiswa dapat mencapai nilai di atas 75 sebanyak $75 \%$. Selanjutnya ningsih juga menambahkan bahwa proses pembelajaran TTW menuntut mahasiswa untuk menyampaikan ide-idenya secara tulisan maupun lisan. Selain itu, pemberian masalah dan penerapan pembelajaran secara kolaboratif pula terbukti dapat mengembangkan kemampuan komunikasi matematis mahasiswa, hal ini sejalan dengan hasil penelitian yang dilakukan (Wahyudin, 2010). Wahyudin menyampaikan bahwa rerata kemampuan komunikasi matematis mahasiswa yang mendapatkan perkuliahan menggunakan strategi kolaboratif berbasis masalah lebih besar daripada rerata kemampuan komunikasi matematis mahasiswa yang mendapatkan perkuliahan konvensional.

\section{DISPOSISI BERPIKIR KRITIS}

Berikut ini akan disajikan pembahasan mengenai disposisi berpikir kritis mahasiswa. Skala disposisi berpikir kritis mahasiswa diberikan setelah mereka mendapatkan pembelajaran dengan pendekatan student centered. Secara umum deskripsi disposisi berpikir kritis mahasiswa dapat dilihat pada Tabel 7 di bawah ini:

Tabel 7

Deskripsi Skala Disposisi Berpikir Kritis Mahasiswa

\begin{tabular}{clcccc}
\hline \multicolumn{1}{c}{$\mathbf{N}$} & \multicolumn{1}{c}{ Minimum } & Maximum & Rata-rata & $\begin{array}{c}\text { Persentase } \\
\text { Pencapaian }\end{array}$ & Kategori \\
\hline \multicolumn{1}{c}{40} & \multicolumn{1}{c}{71} & 101 & 84.78 & $76 \%$ & Baik \\
\hline S & : Jumalah Mahasiswa & & & \\
Skor Total & $: 112$
\end{tabular}

Berdasarkan tabel di atas, terlihat bahwa setelah pembelajaran dengan pendekatan student learning, secara keseluruahan mahasiswa memiliki kemampuan disposisi berpikir kritis yang tergolong baik.
Berikut ini akan disampaikan deskripsi disposisi berpikir kritis mahasiswa berdasarkan masing-masing kategori KAM pada Tabel 8 di bawah ini: 
Tabel 8

Deskripsi Skala Disposisi Berpikir Kritis Mahasiswa Berdasarkan Kategori Kemampuan Awal Matematis (KAM)

\begin{tabular}{ccc}
\hline $\begin{array}{c}\text { Kemampuan } \\
\text { Awal Matematis }\end{array}$ & \% Pencapaian & Kategori \\
\hline Tinggi & 77 & Baik \\
\hline Sedang & 76 & Baik \\
\hline Rendang & 72 & Baik \\
\hline
\end{tabular}

Berdasarkan Tabel 8, terlihat bahwa disposisi berpikir kritis pada setiap kategori KAM tergolong baik, hal ini menunjukan bahwa pembelajaran dengan pendekatan Student Centered memberikan hasil yang baik pada disposisi berpikir kritis mahasiswa pada semua kategori KAM. Pembelajaran dengan pendekatan student centered, memberikan kesempatan bagi mahasiswa untuk dapat mengembangkan kemampuan komunikasi matematis mereka. Namun selain itu, pada implementasinya, sebelum mahasiswa dapat mengemukakan ide-ide matematis mereka dalam bentuk lisan dan tulisan. Mahasiswa terlebih dahulu dituntut untuk memiliki kesadaran dalam berpikir kritis.

Pada awal pemberian masalah dan tugas mandiri, mahasiswa dituntut untuk dapat bertanya dan memberikan alasan secara jelas mengenai konsep apa yang akan mereka pelajari dan kebermanfaatan konsep tersebut dalam kehidupan sehari-hari, selain itu mahasiswa dituntut untuk memiliki usaha dalam memahami masalah atau tugas yang akan mereka selesaikan dengan bantuan sumber-sumber belajar yang terpercaya. Baik itu berasal dari buku, hasil percobaan dan referensi lainnya. Setelah mahasiswa dapat menyelesaikan permasalahan atau tugas yang diberikan, mahasiswa juga dituntut untuk mencari alternatif lain dalam menyelesaikan masalah atau tugas yang diberikan. Keseluruhan rangkaian kemampuan yang harus mahasiswa miliki sebelum dan setelah menyelesaikan tugas yang diberikan, merupakan bagian dari indicator disposisi berpikir kritis. Sehingga, tanpa mahasiswa sadari, kesadaran berpikir kritis mahasiswa akan berkembang selama melalui pembelajaran dengan pendekatan student centered.

Pemaparan di atas sejalan dengan hasil penelitian (Angraini, 2013) yang menyatakan bahwa pembelajaran dengan concept attainment model (CAM) memberikan pengaruh yang baik pada disposisi berpikir mahasiswa. Angraini menambahkan bahwa pembelajaran dengan CAM menghasilkan disposisi berpikir kritis yang lebih baik dibandingkan dengan pembelajaran konvensional. Pembelajaran CAM merupakan slaah satu pembelajaran yang menggunakan pendekatan Student Centered.

\section{KESIMPULAN DAN SARAN}

Berdasarkan rumusan masalah, hasil penelitian dan pembahasan yang telah dikemukakan pada bab sebelumnya, diperoleh kesimpulan sebagai berikut: (1) Peningkatan kemampuan kominikasi matematis mahasiswa pada mata kuliah matematika diskrit melalui pembelajaran dengan pendekatan student centered, secara umum dapat dikatakan cukup signifikan. Selanjutnya, mahasiswa dengan KAM tinggi dan sedang mengalami peningkatan yang cukup signifikan dengan dengan pembelajaran melalui pendekatan student centered. Sedangkan, peningkatan kemampuan komunikasi matematis mahasiswa pada kategori KAM rendah dpat dikatakan tidak signifikan, dengan kategori peningkatan n-gain rendah; (2) Disposisi berpikir kritis mahasiswa pada mata kuliah matematika diskrit setelah mengikuti pembelajaran dengan pendekatan Student Centered memiliki kategori baik dengan presentasi pencapaian rata-rata skor disposisi matematis dibandingkan dengan skor total 
mencapai $76 \%$. Hal ini juga terlihat pada rerata pencapaian skala disposisi berpikir kritis mahasiswa pada masing-masing kategori KAM. Mahasiswa pada kategori KAM tinggi memperoleh pencapaian skala disposisi berpikir kritis sebesar 77\%, $76 \%$ pada mahasiswa dengan kategori KAM sedang dan $72 \%$ pencapaian disposisi $72 \%$. Tidak seperti tes kemampuan komunikasi matematis, disposisi berpikir kritis mahasiswa pada setiap kategori KAM memberikan pencapaian yang seragam, yaitu masuk dalam kategori baik.

Berdasarkan kesimpulan dan implikasi dari penelitian ini, diajukan beberapa saran sebagai berikut: (1) Perlunya pembinaan yang lebih dalam pada kelompok mahasiswa khususnya pada kategori KAM rendah. Pembinaan dapat dilakukan oleh dosen yang bersangkutan atau penyusunan kelompokkelompok belajar dan tutor sebaya. (2) Walaupun disposisi berpikir kritis mahasiswa pendidikan matematika FKIP Unswagati sudah baik, namun tetap perlu diadakan pembinaan mengenai pembiasaan senang belajar dan pembinaan akademik yang lebih mendalam oleh dosen wali atau prodi mengenai kesulitan dan kesadaran mahasiswa khususnya dalam berpikir kritis.

\section{DAFTAR RUJUKAN}

Angraini, L. M. (2013). Pengaruh Concept Attainment Model Terhadap Kemampuan Komunikasi Dan Berpikir Kritis Serta Disposisi Berpikir Kritis Matematis Mahasiswa Pgmi. Bandung: SPs UPI Bandung.

Cottrell. (2005). Critical Thiking Skill. New York: Palgrave Macmillan.

Hendriana. (2009). Pembelajaran dengan Pendekatan Metaphorical Thinking untuk Meningkatkan Kemampuan Pemahaman Matematik, Komunikasi Matematik dan Kepercayaan Diri Siswa Sekolah Menengah Pertama. Bandung: SPs UPI Bandung.
Jones, L. (2007). The Student Centered Classroom. New York: Cambridge University Press.

Kadir. (2010). Penerapan Pembelajaran Kontekstual Berbasis Potensi Pesisir sebagai Upaya Peningkatan Kemampuan Pemecahan Masalah Matematik, Komunikasi Matematik dan Keterampilan Sosial Siswa SMP. Bandung: SPs UPI Bandung.

Karmilah. (2010). Mengembangkan Kemampuan Komunikasi dan Pemecahan Masalah Serta Disposisi Matematis Mahasiswa PGSD melalui Pembelajaran Berbasis Masalah. Bandung: SPs UPI Bandung.

Kurni, F. N. (2009). Penerapan StudentCentered Learning dari TeacherCentered Learning Mata Ajar Ilmu Kesehatan Program Studi Penjaskes. 28 (2).

NCTM. (2000). Principles and Standards for School Mathematics. Virgina: Reston.

Ningsih, S. C. (2014). Mengembangkan Kemampuan Komunikasi Matematis Mahsiswa Pendidikan Matematika UPY Melalui Model Pembelajaran ThinkTalk-Write. Yogyakarta: Universitas PGRI Yogyakarta.

Rosita, C. D., \& Nopriana, T. (2016). Analisis Tingkat Berpikir Geometri dan Tingkat Berpikir Logis serta Disposisi Berpikir Kritis Mahasiswa. Prosiding SNMPM 2016 Prodi Pendidikan Matematika FKIP Unswagati. Cirebon: FKIP Unswagati.

Sumarmo, U. (2013). Berpikir dan Disposisi Matematika Serta Pembelajarannya. Bandung: FMIPA UPI Bandung.

U.S Department of Education. (2010). Student Centered Learning. America: American Institute for Reasearch. 
Widjayanti, D. B., \& Wahyudin. (2010). Son, L. (2015). Pentingnya Kemampuan Mengembangkan Kemampuan Komunikasi Matematika Bagi Komunikasi Matematis Mahasiswa Mahasiswa Calon Guru Matematika. Calon Guru Matematika Melalui Gema Wiralodra Vol VII No 1. Strategi Perkuliahan Kolaboratif Indramayu: Universitas Wiralodra.

Berbasis Masalah. Konferensi Nasional Matematika 2010. Yogyakarta : Universita Negeri Yogyakarta. 